\title{
A bradykinin $(\mathrm{BK})_{1}$ receptor antagonist blocks capsaicin-induced ear inflammation in mice
}

\author{
${ }^{1}$ Charles R. Mantione \& Richard Rodriguez
}

Nova Pharmaceutical Corporation, 6200 Freeport Centre, Baltimore, Maryland 21224-2788, U.S.A.

\begin{abstract}
1 The effect of various peptide antagonists on capsaicin-induced ( $250 \mu \mathrm{g}$ per ear) ear inflammation has been examined.

2 Co-administration of the substance P (SP) antagonist [D-Pro $\left.{ }^{2}, \mathrm{D}-\mathrm{Trp}^{7,9}\right] \mathrm{SP}$ at 100 and $300 \mu \mathrm{g}$ per ear with capsaicin markedly attenuated oedema, whereas a vasopressin antagonist was ineffective.

3 Using the same scheme, the mixed $\mathrm{BK}_{2}$ and $\mathrm{BK}_{1}$ bradykinin (BK) antagonist NPC 567 (D-Arg[Hyp ${ }^{3}$, D-Phe $\left.\left.{ }^{7}\right] \mathrm{BK}\right)$ did not inhibit oedema at $100 \mu \mathrm{g}$ per ear, but did inhibit at a higher dose $(300 \mu \mathrm{g})$. The $\mathrm{BK}_{1}$ antagonist $\left[\mathrm{Leu}^{8}\right.$,es Arg $\left.^{9}\right] \mathrm{BK}$ produced significant inhibition at both doses.

4 When BK was used to induce ear inflammation ( $30 \mu \mathrm{g}$ per ear), the SP antagonist inhibited ear oedema. Both $\mathrm{BK}$ receptor subtype antagonists inhibited inflammation with the $\mathrm{BK}_{1}$ being more potent than the $\mathrm{BK}_{2}$ antagonist.

5 These results suggest that $\mathrm{BK}_{1}$ along with $\mathrm{BK}_{2}$ receptors are located on capsaicin-sensitive fibres, where they may modulate the degree of neurogenic inflammation.
\end{abstract}

\section{Introduction}

It is well known that capsaicin specifically stimulates primary sensory pain fibres to release substance $P$ (SP) and other tachykinins (Nagy et al., 1981; Jancso et al., 1985; Hoover, 1987). The release of SP, an 11 amino acid neuropeptide, by capsaicin and other noxious stimuli may be involved in the generation of local inflammatory responses via an axon reflex (Lembeck \& Holzer, 1979). There is further evidence that bradykinin (BK) will also release SP from capsaicin-sensitive nerves (Butler \& Hammond, 1980; Hakanson et al., 1987; Geppetti et al., 1988). BK itself is a nonapeptide involved in many biological processes. It is released during tissue damage, causing increased vascular permeability, vasodilatation, and pain (Regoli \& Barabe, 1980). Since there appear to be at least two different types of receptors involved in mediating BK effects in tissues (Regoli \& Barabe, 1980; Bouthillier et al., 1987), it was of interest to determine which receptor subtype, $\mathrm{BK}_{1}$ or $\mathrm{BK}_{2}$, is involved in the control of neurogenic inflammation.

In most tissues $\mathrm{BK}$ acts on $\mathrm{BK}_{2}$ receptors which are sensitive to BK and kallidin (Lys-BK) much more than to any other kinin. As originally noted by Regoli \& Barabe (1980), vascular smooth muscle develops responsiveness to the normally inactive metabolites, desArg ${ }^{9} \mathrm{BK}$, and desArg ${ }^{10}$ kallidin. This subset of BK receptors has been termed type 'BK', Further studies have shown that enhancement of $\mathrm{BK}_{1}$ receptor induction in vitro is produced by exposure to lipopolysaccharide in vivo (Bouthillier et al., 1987). In these experiments, development of a $\mathbf{B K}_{1}$ receptor response requires several hours to be detectable.

Capsaicin-induced neurogenic inflammation in mouse ears has a rapid onset (unpublished data). Thus, this model of inflammation presented a simple assay to test whether the BK receptor controlling $\mathrm{SP}$ release was of the stable $\mathrm{BK}_{2}$ or the inducible $\mathrm{BK}_{1}$ subtype.

\section{Methods}

Groups of 6-10 male albino mice, 25-30 $\mathrm{g}$ (Charles River, NY) were anaesthetized with isoflurane. Vehicle or capsaicin $\left(25 \mathrm{mg} \mathrm{ml}^{-1}\right)$ or capsaicin plus peptide was applied by a pipette to the right ear, $5 \mu \mathrm{l}$ to both the dorsal and ventral

\footnotetext{
${ }^{1}$ Author for correspondence.
}

surface. Animals were anaesthetized $30 \mathrm{~min}$ later, and killed by cervical dislocation. Both the right (treated) and left (untreated) ear were removed by cutting horizontally across the indentation at the base of the ear. Weights were determined to the nearest tenth of a mg.

The percentage inhibition of oedema formation was calculated as follows: the weight of the untreated ear was subtracted from the treated ear in each group (vehicle, irritant, drug). The mean irritant oedema was obtained by subtracting the average vehicle control ear weight from the average capsaicin-treated ear weight. The \% inhibition of oedema by peptides was calculated by subtracting the average vehicle oedema value from each ear weight in the drug group, and that mean was divided by the difference between the irritant and vehicle groups. The resultant value was subtracted from one and multiplied by 100 .

Capsaicin and peptides were dissolved in ethanol. For BKinduced oedema, BK was prepared with captopril, each at concentrations of $3 \mathrm{mg} \mathrm{ml}^{-1}$ to achieve a dose of $30 \mu \mathrm{g}$ per ear. All peptides and peptide antagonists were dissolved in dimethyl sulphoxide. Peptides and drugs for these studies came from the following sources: capsaicin (Fluka, N.Y.); BK, $\left[\mathrm{Leu}^{8}, \mathrm{desArg}^{9}\right] \mathrm{BK},\left[\mathrm{D}-\mathrm{Pro}^{2}, \mathrm{D}-\mathrm{Trp}^{7,9}\right] \mathrm{SP}$, and [1-mercaptocyclohexyl] acetyl-Tyr[Me] Arg $^{8}$-vasopressin (Sigma, St. Louis, MO.). NPC 567 (Arg[ $\left.\left.\mathrm{Hyp}^{3}, \mathrm{D}-\mathrm{Phe}^{7}\right] \mathrm{BK}\right)$ was synthesized at NOVA.

Statistical analysis was performed by Student's $t$ test for unpaired observations.

\section{Results \\ Inhibition of capsaicin oedema}

Depending on the type of receptor antagonist, quantitatively different degrees of inhibition of capsaicin-induced oedema (250 $\mu \mathrm{g}$ per ear) were produced (Figure 1). At a concentration of $100 \mu \mathrm{g}$ per ear, the SP antagonist, [D-Pro $\left.{ }^{2}, \mathrm{D}-\operatorname{Trp}^{7,9}\right] \mathrm{SP}$ inhibited inflammation by $42 \%$, which was not significantly altered by increasing the dose to $300 \mu \mathrm{g}$ per ear $(52 \%)$. For comparison, an arginine vasopressin (AVP) receptor antagonist had no effect at $100 \mu \mathrm{g}$ per ear. We tested the effects of BK by using both a mixed $\mathrm{BK}_{1}$ and $\mathrm{BK}_{2}$ receptor antagonist, NPC 567, and a specific $\mathrm{BK}_{1}$ receptor antagonist, [Leu ${ }^{8}$, desArg ${ }^{9}$ ]BK. At $100 \mu \mathrm{g}$ per ear, NPC 567 did not produce any appreciable inhibition of oedema, but at $300 \mu \mathrm{g}$ it did cause a significant, $34 \%$, inhibition of inflammation. On the other 


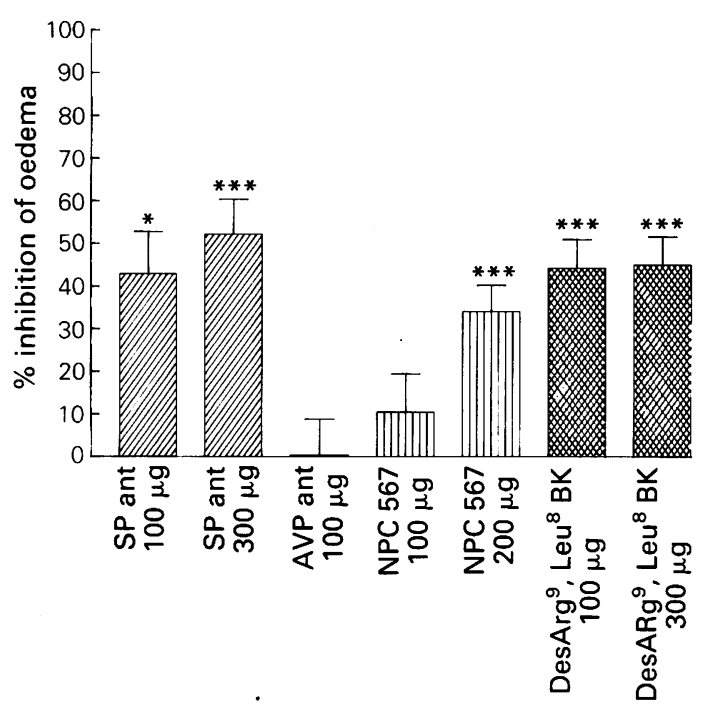

Figure 1 Inhibition of capsaicin oedema by various peptides. A dose of $250 \mu$ g capsaicin per ear produced a $36 \pm 1.0 \%(n=6)$ increase in ear weight. The substance $P$ antagonist (SP ant) was [D-Pro ${ }^{2}, D-$ $\operatorname{Trp}^{7,9}$ ] bradykinin (BK) and AVP ant $=$ arginine vasopressin antagonist. Peptides were topically co-administered with capsaicin $(250 \mu \mathrm{g})$ and oedema measured $30 \mathrm{~min}$ later. Values represent the mean of 20-30 mice, and vertical bars show s.e.mean. Statistically significant differences are represented as follows: ${ }^{*} P<0.05,{ }^{* * *} P<0.001$.

hand, the $\mathrm{BK}_{1}$ antagonist caused $40 \%$ inhibition at $100 \mu \mathrm{g}$ per ear, and non-significantly increased it to $45 \%$ at a dose of $300 \mu \mathrm{g}$.

\section{BK-induced oedema}

We investigated whether kinins can cause ear oedema, and the ability of various peptide antagonists to inhibit this inflammation (Figure 2). BK $(30 \mu \mathrm{g})$ was a potent stimulant of inflammation when applied to the ear, the response was effectively inhibited $(131 \%)$ by a single dose $(300 \mu \mathrm{g})$ of NPC 567 applied to the ear. [ $\mathrm{Leu}^{8}$, desArg $\left.^{9}\right] \mathrm{BK}$ produced a lower effect $(27 \%)$ at $300 \mu \mathrm{g}$ per ear (data not shown). The SP antagonist $(100 \mu \mathrm{g})$

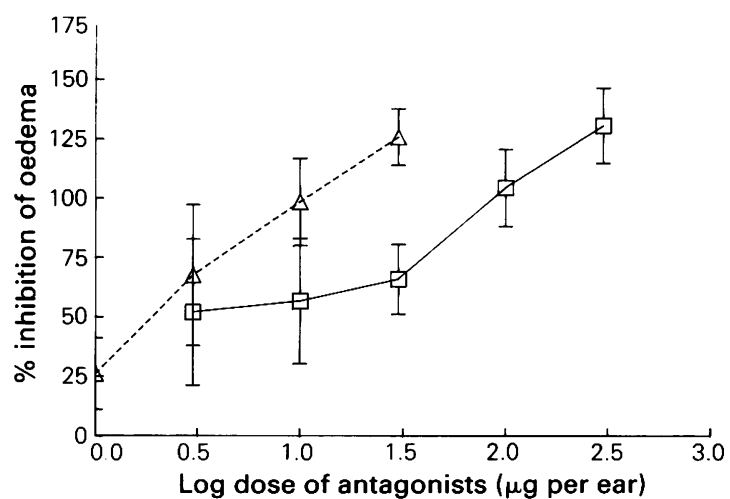

Figure 2 Dose-response curves for the inhibition of bradykinininduced oedema by $\mathrm{BK}_{1}$ - and $\mathrm{BK}_{2}$-receptor antagonists. $\mathrm{BK}$ itself produced $48 \pm 5.1 \%(n=6)$ oedema. The $\mathrm{ED}_{50}$ for NPC $567(\square)$ was $16.2 \mu \mathrm{g}$ per ear and that for $\left[\mathrm{Leu}^{8}, \mathrm{desArg}^{9}\right] \mathrm{BK}(\triangle) 2.0 \mu \mathrm{g}$ per ear. Each point represents the mean of 10 mice and vertical lines show s.e.mean.

\section{References}

BOUTHILliER, J., DEBLOIS, D. \& MARCEAU, F. (1987). Studies on the induction of pharmacological responses to desArg ${ }^{9}-\mathrm{BK}$ in vitro and in vivo. Br. J. Pharmacol., 92, 252-264. was as effective against BK-induced oedema $(58 \%)$ as it was against capsaicin-induced oedema (Figure 1: 52\%).

The dose-response relationship between oedema and the concentration of NPC 567 and $\left[\mathrm{Leu}^{8}\right.$,desArg $\left.{ }^{9}\right] \mathrm{BK}$ was investigated. In Figure 2, [ Leu $^{8}$,desArg $\left.{ }^{9}\right] B K$ is clearly shown to be a more potent inhibitor of oedema than NPC 567. In fact, the BK $_{1}$ antagonist reached a maximum of $100 \%$ inhibition at $30 \mu \mathrm{g}$ per ear (Figure 2), then began to become less effective at higher concentrations (data not shown). Figure 2 demonstrates that the mixed $\mathrm{BK}_{2}$ and $\mathrm{BK}_{1}$ receptor antagonist, NPC 567, inhibited about $50 \%$ of the oedema produced, which is similar to the effect of $\left[\mathrm{Leu}^{8}, \mathrm{des} A \mathrm{Arg}^{9}\right] \mathrm{BK}$ at low concentrations. At high concentrations of both antagonists there was a greater than $100 \%$ inhibition. This stems from the inhibitory effect on oedema produced by the DMSO vehicle alone. The peptide antagonist did not affect basal (nonvehicle) control ear weight. The linear transformation of the data indicated that the ED ${ }_{50}$ for NPC 567 was $16.2 \mu \mathrm{g}$ per ear, whereas [ $\mathrm{Leu}^{8}$,desArg $\left.{ }^{9}\right] \mathrm{BK}$ had an $\mathrm{ED}_{50}$ of $2.0 \mu \mathrm{g}$ per ear. Thus, based on these results, the existence of endogenous BK $_{1}$ receptors are implied.

\section{Discussion}

Co-administration of a $\mathrm{BK}_{1}$ receptor antagonist, [Leu ${ }^{8}$, desArg ${ }^{9}$ ]BK with capsaicin reduced neurogenic inflammation. Another peptide, D-Arg $\left[\mathrm{Hyp}^{3}, \mathrm{D}-\mathrm{Phe}^{7}\right] \mathrm{BK}$, which is a partial $\mathrm{BK}_{2}$ receptor antagonist (Regoli et al., 1986), was less effective at blocking this type of inflammation. That the SP antagonist, $\left[\mathrm{D}-\mathrm{Pro}^{2}, \mathrm{D}-\mathrm{Trp}^{7,9}\right] \mathrm{SP}$, was effective at inhibiting capsaicininduced oedema suggests that SP release by capsaicin may be the primary mediator of inflammation in this model.

Moreover BK-induced inflammation in the mouse ear was also strongly inhibited by the same SP antagonist. Others have shown that the intravenous injection of an SP antagonist reduces BK-induced vascular permeability (Shibata et al., 1986). The effects of these peptide antagonists were specific. For example, a vasopressin receptor antagonist did not inhibit oedema formation induced by capsaicin. These results suggest that both $\mathrm{BK}_{1}$ and $\mathrm{BK}_{2}$ receptors are able to modify the capsaicin-induced release of SP, and thus influence the development of neurogenic inflammation.

BK $_{1}$ receptors have characteristically been shown not to be present in normal tissue, but synthesized upon tissue injury (Regoli \& Barabe, 1980). This can also be seen when rabbits are treated intravenously with endotoxin where $\mathbf{B K}_{1}$ receptormediated hypotension is seen $6 \mathrm{~h}$ after treatment (Bouthillier et al., 1987). Capsaicin-induced inflammation, as measured by an increase in ear weight, is already maximal at $30 \mathrm{~min}$ post application (data not shown). This suggests that $\mathrm{BK}_{1}$ receptors are normally present on sensory fibres in the mouse ear. BK and its kininase II metabolite desArg ${ }^{9}$ BK can then act at their respective receptors to amplify the inflammatory process further. In fact, BK has been shown to have a synergistic effect with SP on vascular permeability and the pain response in the mouse paw (Shibata et al., 1986).

Thus, these data demonstrate the endogenous presence of $\mathrm{BK}_{1}$ receptors on capsaicin-sensitive nerves without the de novo synthesis of these receptors with tissue injury. In the ear they appear to regulate the degree of neurogenic inflammation. Further studies are in progress to measure directly BK $_{1}$ receptors in ear tissue and elsewhere, by using radioligand binding techniques with desArg ${ }^{10} \mathrm{kallidin}$ as the ligand.
BUTLER, J.M. \& HAMMOND, B.R. (1980). The effects of sensory denervation in the response of the rabbit eye to prostaglandin $E_{1}$, bradykinin and substance P. Br. J. Pharmacol., 69, 495-502. 
GEPPETTI, P., MAGGI, C.A., PERRETTI, F., FRILLI, S. \& MANZINI, S. (1988). Simultaneous release of bradykinin, substance $P$ and calcitonin gene-related peptide immunoreactivities from capsaicin sensitive structures in guinea-pig heart. Br. J. Pharmacol., 94 288-290.

HAKANSON, R., BEDING, B., EBMAN, M., WAHLESTEDT, C. \& SUNDLER, F. (1987). Multiple tachykinin pools in sensory nerve fibers in the rabbit iris. Neuroscience, 4, 943-950.

HOOVER, D.B. (1987). Effects of capsaicin on release of substance P-like immunoreactivity and physiological parameters in isolated perfused guinea-pig heart. Eur. J. Pharmacol., 141, 489-492.

JANSCO, G., FERENCSIK, M., SUCH, G., KIRALY, E., NAGY, A. \& BUJDOSO, M. (1985). Morphological effects of capsaicin and its analogues in newborn and adult mammals. In Tachykinins Antagonists, ed. Hakanson, R. \& Sundler, F. pp. 35-44. New York: Elsevier Science.
LEMBECK, F. \& HOLZER, P. (1979). Substance P as a neurogenic mediator of antidromic vasodilation and neurogenic plasma extravasation. Arch. Pharmacol., 310, 175-183.

NAGY, J.I., HUNT, S.P., IVERSEN, L.L. \& EMSON, P.C. (1981). Biochemical and anatomical observation on the denervation of peptide containing primary afferent neurons after neonatal capsaicin. Neuroscience, 6, 1923-1934.

REGOLI, D. \& BARABE, J. (1980). Pharmacology of bradykinin and related kinins. Pharmacol. Rev., 32, 1-46.

REGOLI, D., DRAPEAU, G., ROVERO, P., D'ORLEANS-JUSTE, P. \& BARABE, J. (1986). The actions of kinin antagonists on $B_{1}$ and $B_{2}$ Receptor systems. Eur. J. Pharmacol., 123, 61-65.

SHIBATA, M., OHKUBO, T., TAKAHSHI, H. \& INOKI, R. (1986). Interaction of bradykinin with substance $\mathbf{P}$ on vascular permeability and pain response. Japan J. Pharmacol., 41, 427-429.

(Received March 21, 1989 Revised September 14, 1989 Accepted November 13, 1989) 